\title{
Infographics and digital resources: an international consensus on golf and health
}

Andrew D Murray, ${ }_{1}^{1,2}$ Christian J Barton, ${ }^{3,4}$ Daryll Archibald, ${ }^{5,6}$ Danny Glover, ${ }^{7}$ lain Robert Murray, ${ }^{8,9}$ Kevin Barker, ${ }^{10}$ Roger A Hawkes ${ }^{11,12}$

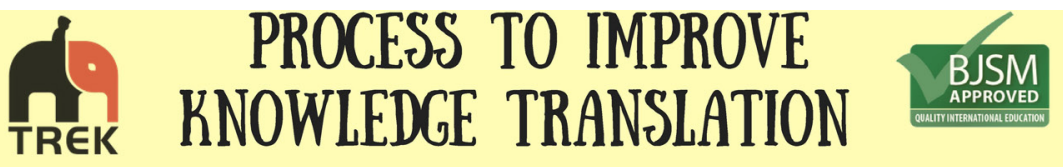

\section{TRADITIONAL STEP 1 AND 2}
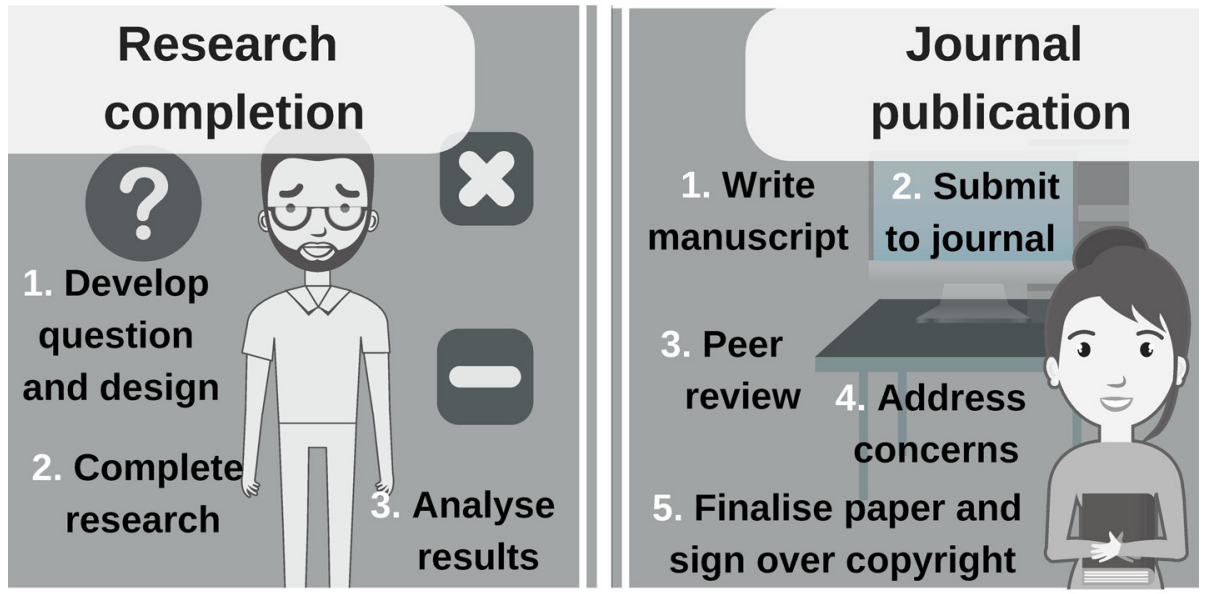

\section{NOVEL STEP 3 AND 4}
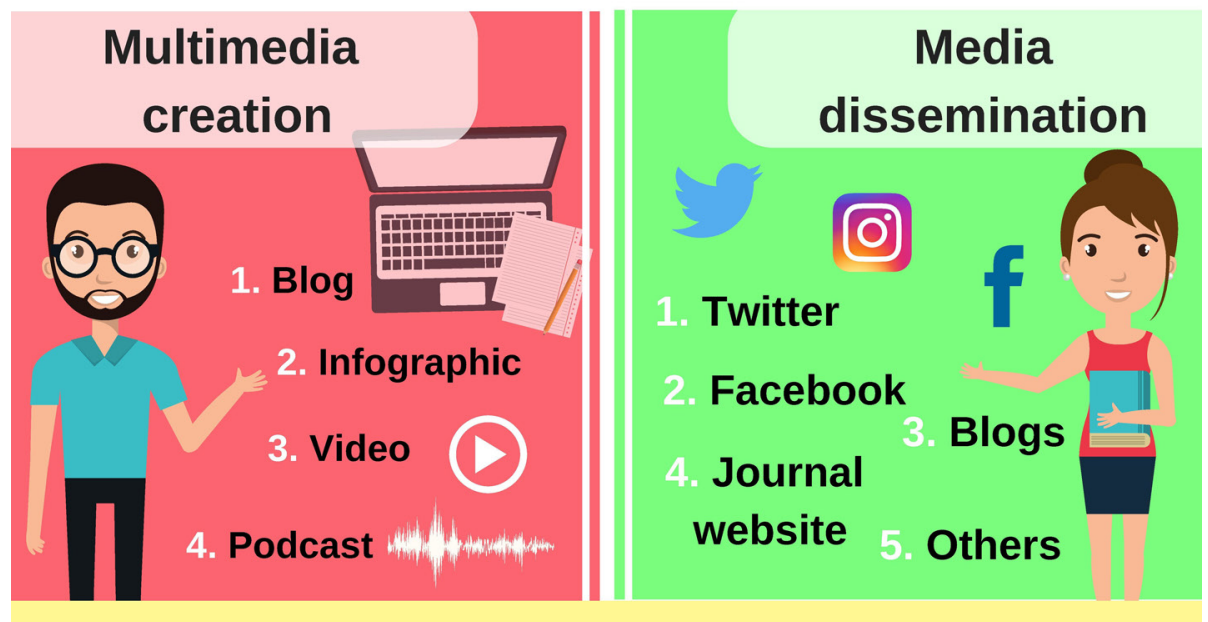

Designed by@fisioterapianet

Barton CJ and Merolli MA, BJSM 2017

Figure 1 Visual representation of a process to improve knowledge translation based on Barton and Merolli's model. ${ }^{2}$

INTRODUCTION

New knowledge from research findings rarely produces rapid efficient changes in practice. ${ }^{1}$ Barton and Merolli ${ }^{2}$ proposed a model which may help improve knowledge translation via the addition of two novel contemporary steps: multimedia creation and subsequent dissemination (see figure 1).

Following this model, we recently produced digital/multimedia resources to help communicate and disseminate the International Consensus on Golf and Health. ${ }^{3}$
RESEARCH COMPLETION AND PUBLICATION

A systematic literature review and modified Delphi process underpinned the International Consensus on Golf and Health and this was published in the British Journal of Sports Medicine in 2018. ${ }^{3}$ The 
Consensus is intended to support (1) golfers and potential golfers; (2) golf facilities and the golf industry; and (3) policy makers to make evidence-informed decisions that can maximise the health benefits of golf and minimise the health risks associated with this sport.

\section{MULTIMEDIA CREATION}

Articles containing visual information are read three times more often than those without. ${ }^{4}$ Humans remember up to 6.5 times more through learning from visual imagery than by reading text alone. ${ }^{5}$ This makes sense. How many text-only adverts do you see? What is your reaction to a wordy PowerPoint presentation? We produced bite-sized resources (infographics, podcasts and video content) with the key messages stemming from the consensus statement. ${ }^{3}$

Infographics have been made to support end-user groups: (1) golf players/potential players; (2) the golf industry/facilities; and (ii) policy makers external to golf. These visual resources highlight the specific actions that can lead to the biggest gains in health and well-being related to golf (see figures 2-4). They complement published infographics regarding golf and health ${ }^{6}$ and maximising golf performance. ${ }^{7}$

Video content was designed to have broad interest. We featured leading players who had won multiple major championships as well as researchers, clinicians and public health ministers. These are available
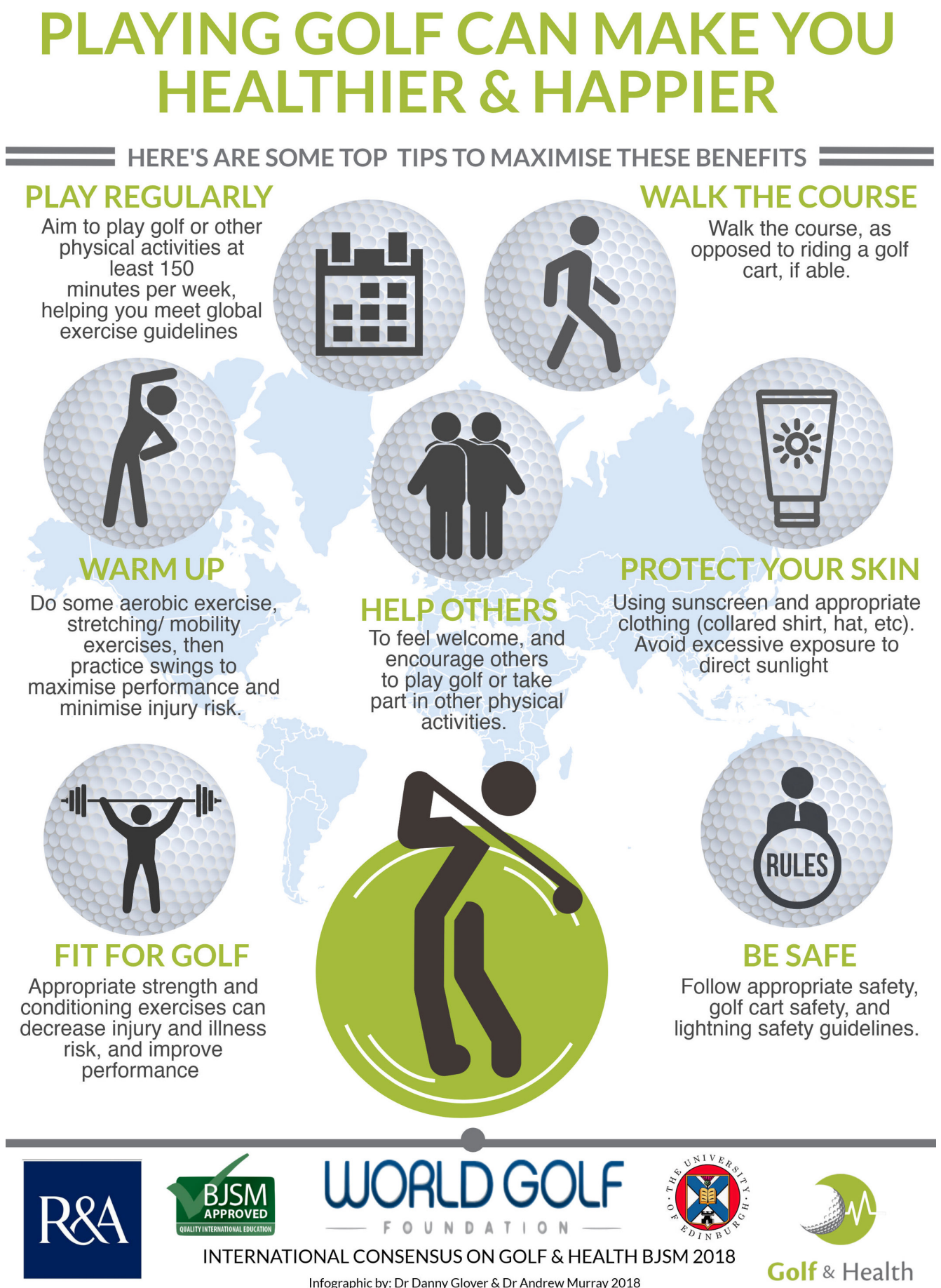

Figure 2 Infographic. Tips to maximise health benefits of golf for golfers. 


\section{WHAT CAN THE GOLF \\ INDUSTRY/FACILITIES DO TO MAXIMISE THE HEALTH BENEFITS OF GOLF?}

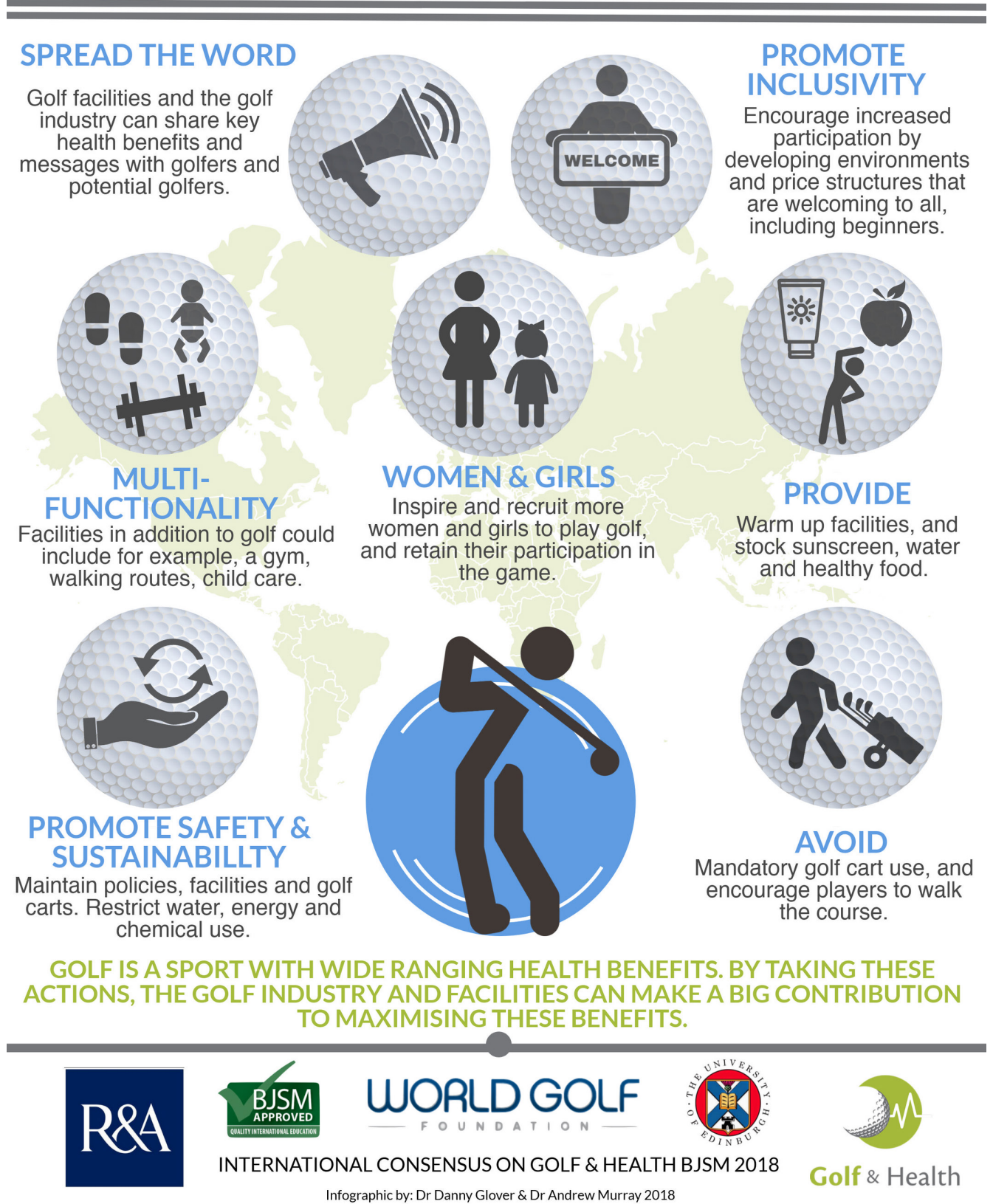

Figure 3 Infographic. What can the golf industry/golf facilities do to maximise the health benefits of golf?

at www.golfandhealth.org. A podcast with more detail discussing the International Consensus on Golf on Health is available at https://soundcloud.com/bmjpodcasts/sets/bjsm-1. It offers researchers and others interested a 'deeper dive' into the methods and findings.

\section{DISSEMINATION AND COMMUNICATION}

Infographics and other multimedia/digital resources facilitate the sharing of key messages and engagement with research.
They are not a substitute for reading the detailed peer reviewed article. Strategies ${ }^{8}$ for sharing content can include:

- social media platforms (eg, via Twitter, Facebook, Instagram and blogs)

- email, plus or minus press release distribution

- direct communications including discussions, meetings and presentations targeting relevant stakeholders.

We used these strategies to share our previous scoping review on golf and health. ${ }^{9}$ This approach to sharing new research may have contributed to this manuscript being the subject of over 90 press articles, a supportive Early Day Motion in the UK parliament and achieving an Altmetric score $>1300$.

\section{CONCLUSION}

Barton and Merolli's model offer researchers strategies to increase the visibility of their work. After conducting an International Consensus on Golf and Health and publishing it in the BJSM, we 


\section{Golf \& Health- key actions for policy/decision makers}

The benefits of regular physical activity should be

communicated and promoted

regularly for persons of all ages, genders, and

socio-economic backgrounds.
Golf can provide health enhancing physical activity to persons of all ages, and genders. Policy documents, frameworks and

actions should support this.

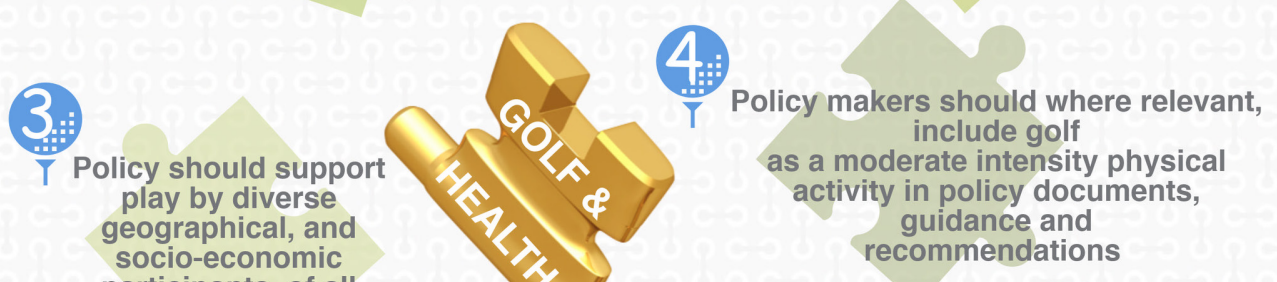
participants, of all genders, ages and abilities

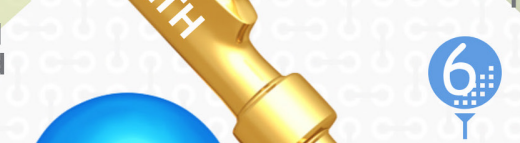

Policy makers should work collaboratively with the golf industry and national associations to promote increased participation in physical activity/golf,

Policies should promote multi-functionality (having facilities in addition

to golf), diversity of facilities where possible, and sustainable practices
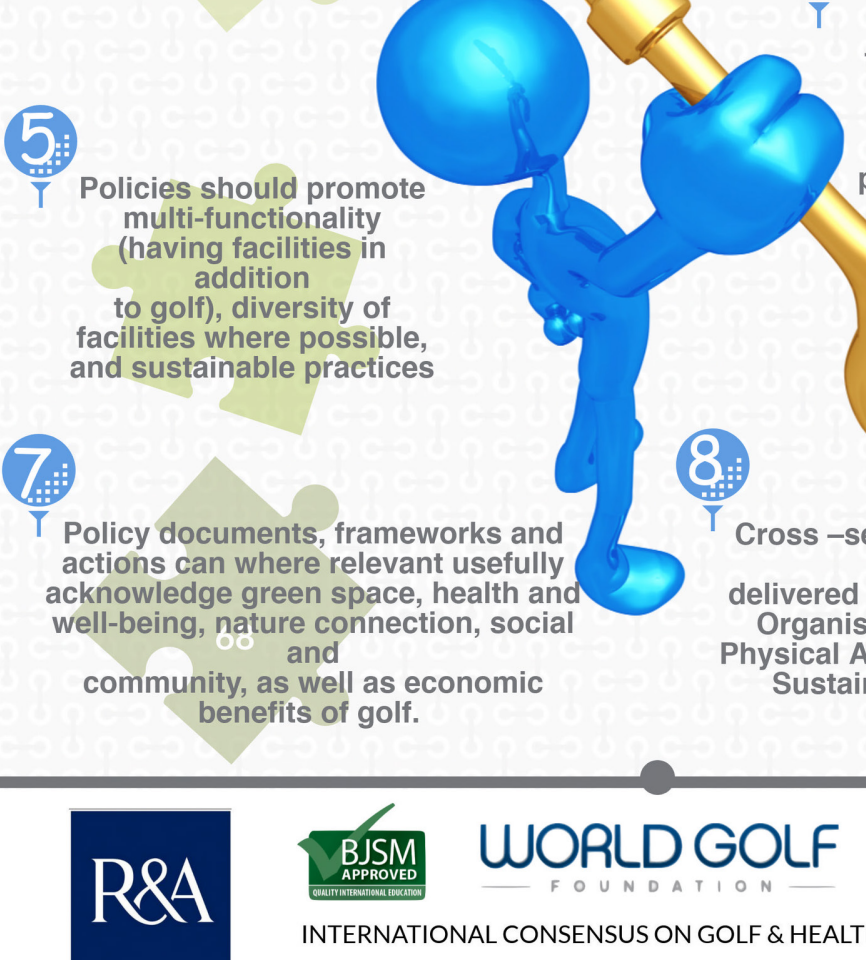

particularly in groups with low levels of physical

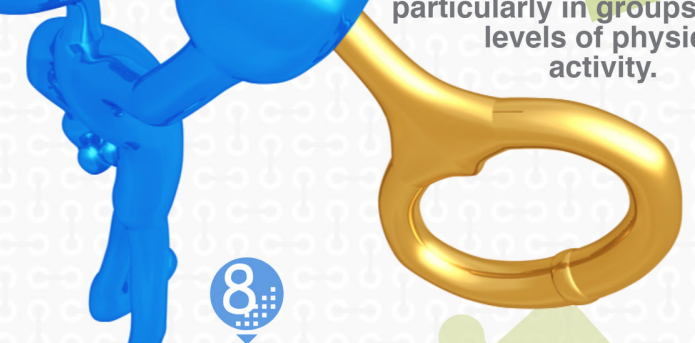

Cross -sectoral policies involving golf can be delivered that support the World Health Organisation Global Action Plan on Physical Activity, and the United Nations Sustainable Development Goals. benefits of golf.
benity, as well as eco

, social en space, health an are cont as economic

INTERNATIONAL CONSENSUS ON GOLF \& HEALTHBJSM 2018

Infographic by: Dr Danny Glover \& Dr Andrew Murray 2018

Golf \& Health

Figure 4 Infographic. Golf and Health: key actions for policy/decision makers.

shared bite-sized multimedia resources to assist the dissemination and communication of the consensus. The BJSM is well positioned to support researchers who wish to produce similar digital resources. Options include, but are not limited to, co-producing podcast and blog content, and sharing purpose-created digital resources via popular Twitter, Facebook, Instagram and YouTube platforms.
${ }^{1}$ Sport and Exercise, Physical Activity for Health Research Centre, University of Edinburgh, Edinburgh, UK

${ }^{2}$ European Tour Golf, Edinburgh, UK

${ }^{3}$ Sport and Exercise Medicine Research Centre, La Trobe University, Bundoora, Victoria, Australia

${ }^{4}$ Complete Sports Care, Hawthorn, Victoria, Australia

${ }^{5}$ School of Psychology and Public health, La Trobe

University, Melbourne, Victoria, Australia

${ }^{6}$ Scottish Collaboration for Public Health Research,

University of Edinburgh, Edinburgh, UK

${ }^{7}$ Health Education Yorkshire and the Humber, Leeds, UK
${ }^{8}$ Department of Trauma and Orthopaedics, The University of Edinburgh, Edinburgh, UK

${ }^{9}$ Orthopaedic Hospital Research Center, University of California, Los Angeles, Los Angeles, California, USA

${ }^{10}$ Golf Development, The R\&A, St Andrews, UK

${ }^{11}$ Golf and Health, World Golf Foundation, St Augustine, Florida, USA

${ }^{12}$ European Disabled Golf Association, Birmingham, UK

Correspondence to Dr Andrew D Murray, Sport and Exercise, Physical Activity for Health Research Centre, University of Edinburgh, Edinburgh EH1 3DG, UK; docandrewmurray@gmail.com 
Acknowledgements The authors thank Nanette Mutrie, Paul Kelly, Liz Grant for academic input and Jorge Rodriguez, Aston Ward, Ed Hodge and Steffan Griffin for their help in creating the infographics, video and podcast content.

Contributors ADM, CJB, IRM, DA and RAH identified the framework and wrote the text. ADM, DG and $\mathrm{KB}$ produced and refined the digital assets. All authors commented on drafts and contributed to the development of the final manuscript and assets.

Funding Work for this study was supported by an unrestricted grant from the World Golf Foundation.

Competing interests $A D M$ is supported by an unrestricted grant from the World Golf Foundation. RAH and ADM receive fees from the European Tour Golf for clinical work. KB is the director of Golf Development at the R\&A.

Patient consent Not required.

Provenance and peer review Not commissioned; internally peer reviewed.

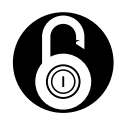

\section{OPEN ACCESS}

Open access This is an open access article distributed in accordance with the Creative Commons Attribution
Non Commercial (CC BY-NC 4.0) license, which permits others to distribute, remix, adapt, build upon this work non-commercially, and license their derivative works on different terms, provided the original work is properly cited, appropriate credit is given, any changes made indicated, and the use is non-commercial. See: http:// creativecommons.org/licenses/by-nc/4.0/.

C Author(s) (or their employer(s)) 2018. Re-use permitted under CC BY-NC. No commercial re-use. See rights and permissions. Published by BMJ.

\section{Check for updates}

To cite Murray AD, Barton CJ, Archibald D, et al. Br J Sports Med 2018;52:1421-1425.

Accepted 21 August 2018

Published Online First 23 September 2018

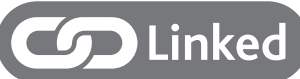

http://dx.doi.org/10.1136/bjsports-2018-099509

Br J Sports Med 2018;52:1421-1425.

doi:10.1136/bjsports-2018-099771

\section{REFERENCES}

1 Morris ZS, Wooding S, Grant J. The answer is 17 years, what is the question: understanding time lags in translational research. J R Soc Med 2011;104:510-20.
2 Barton CJ, Merolli MA. It is time to replace publish or perish with get visible or vanish: opportunities where digital and social media can reshape knowledge translation. Br I Sports Med 2017. doi: 10.1136 bjsports-2017-098367. [Epub ahead of print 16 Nov 2017].

3 Murray AD, Murray IR, Kelly P, et al. The 2018 International Consensus Statement on golf and health to guide action by people, policy makers and the golf industry. Br J Sports Med. In Press. 2018.

4 Ibrahim AM, Lillemoe KD, Klingensmith ME, et al. Visual abstracts to disseminate research on social media: a prospective, case-control crossover study. Ann Surg 2017;266:46-8.

5 Krum R. Cool infographics: effective communication with data visualization and design. Hoboken: Wiley, 2013:4-22.

6 Murray AD, Daines L, Archibald D, et al. Infographic. Golf and health. Br I Sports Med 2017:51:20-1.

7 Tilley N, Murray A, Hillman R, et al. Infographic: how to maximise your golf performance. $\mathrm{Br} J$ Sports $\mathrm{Med}$ 2018;52:413-4.

8 Murray AD, Murray IR, Barton C, et al. Increasing research visibility to maximise impact. Bone Joint J. 2018. Online first

9 Murray AD, Daines $L$, Archibald $D$, et al. The relationships between golf and health: a scoping review. $\mathrm{Br} J$ Sports Med 2017;51:12-19. 